\title{
Assessment and comparison of selenium-enriched maize with sodium selenite and sodium selenate

\author{
${ }^{1}$ Garousi, Farzaneh-2 Veres Szilvia-1 Bódi Éva- ${ }^{1}$ Várallyay Szilvia- ${ }^{1}$ Kovács Béla \\ University of Debrecen Faculty of Agricultural and Food Sciences and Environmental Management, \\ ${ }^{1}$ Institute of Food Science, Debrecen \\ ${ }^{2}$ Institute of Crop Sciences, Debrecen \\ farzaneh@agr.unideb.hu
}

\begin{abstract}
SUMMARY
Selenium is an element of environmental interest owing to the narrow range between its nutritionally required and toxic concentrations in many organisms. Its mobility and bioavailability differ greatly depending on individual Se species. In this regard, in present study, the uptake and distribution of Se, the changes in Se content, and the effects of different concentration of Se in two forms of sodium selenite and sodium selenate on maize plants were measured in nutrient solution experiments to clarify their response to the two forms of Se. The results revealed that the Se content in shoots and roots of maize plants significantly increased as the Se level increased. Two Se forms behaved differently and the effects of toxic damage in samples which had been treated with selenite were much more than in the selenate treatments.
\end{abstract}

Keywords: maize, sodium selenite, sodium selenate

\section{ÖSSZEFOGLALÁS}

A szelénnel kapcsolatos kutatásokat elsősorban az indokolja, hogy számos élölény esetén a táplálkozási szempontból szükséges és a toxikus koncentráció nagyon közel esik egymáshoz. A szelén mobilitása és biológiai hozzáférhetösége elsösorban az adott szelén speciesztöl (módosulattól) függ. A kutatásunk célja ebböl adódóan a szelén felvételének és növényen belüli megoszlásának vizsgálata, illetve annak meghatározása, hogy a különbözö szelénformák (nátrium-szelenit, nátrium-szelenát) hogyan hatnak a kukorica csiranövények szeléntartalmára tápoldatos kisérletben. Kísérletünk során azt tapasztaltunk, hogy a szelén kezelések hatására a kukorica hajtásának és gyökerének szelén koncentrációja szignifikánsan emelkedett. A két szelénforma hatásának tekintetében azonban eltérést figyeltünk meg, a toxikus hatás sokkal eröteljesebben jelentkezett szelenit kezelés esetén.

Kulcsszavak: kukorica, nátrium-szelenit, nátrium-szelenát

\section{INTRODUCTION}

Selenium (Se) is a naturally occurring trace element which is toxic at high concentrations, but it is also an essential element for many organisms (Fan et al. 2002). An optimal supply of Se is important because it can support protection against several diseases, like different type of cancers, prostate, lung, gastrointestinal (Clark et al. 1998, Della Rovere et al. 2006, Grau et al. 2006). Agronomic bio fortification can increase Se concentration in crops and hence dietary intake of Se (Eurola et al. 2004, Eurola 2005, Lyons et al. 2005, White and Broadley 2009, Broadley et al. 2010).

Se can occur in four oxidation states (elemental $\left(\mathrm{Se}^{0}\right)$, selenite $\left(\mathrm{Se}^{4+}\right)$, selenate $\left(\mathrm{Se}^{6+}\right)$ and selenide $\left(\mathrm{Se}^{2-}\right)$ (Canton and Van Derveer 1997). Due to the high solubility of selenite $\left(\mathrm{Se}^{\mathrm{IV}}\right)$ and selenate $\left(\mathrm{Se}^{\mathrm{VI}}\right)$, these forms are more available to plants (Carvalho and Martin 2001) and are important in bio geological and biochemical cycle of Se but since they exhibit different biochemical properties, their toxicity and energy consumption during uptake and metabolism are different (Shen et al. 1997, Weiller et al. 2004).

Despite substantial literature on Se uptake by plants and crops such as wheat, little consideration has been given to maize, low "Se-indicator" plant (Ježek et al. 2012). To date there have been few publications on $\mathrm{Se}$ uptake and assimilation in this plant. Therefore, in this study we selected maize (Zea mays L.) because it is widely used plant cultured throughout the world and is important source of Se for human diet. Maize is nonSe-accumulator plant and the threshold Se toxicity concentration is dependent on the form of Se accumulated (Terry et al. 2000).

Then, we decided to enrich maize plants with Se in both forms of sodium selenite and sodium selenate as well as investigation and comparison of their uptake and distribution to two main parts of shoot and root.

\section{MATERIAL AND METHODS}

\section{Materials}

Sodium selenite and sodium selenate were obtained from Sigma-Aldrich Ltd. (Poole, UK). Nitric acid (69\% ACS, VWR, Lutter-worth, UK) hydrogen-peroxide (30\%, Suprapure grade), and rhodium (1000 $\left.\mathrm{mg} \mathrm{L}^{-1}\right)$ for internal standard were obtained from Fluka (Poole, UK). Selenium (1000 $\left.\mathrm{mg} \mathrm{L}^{-1}\right)$ reference solution for ICP-MS calibration was supplied by Scharlau Chemie (Germany).

\section{General plant propagation}

Maize (Zea mays L. cv. Norma SC) as a monocotyledon plant was chosen for our research. Disinfected maize seeds were geotropically germinated between moist filter papers at $22^{\circ} \mathrm{C}$. Maize seedlings with 2.5 $3.0 \mathrm{~cm}$ coleoptile were placed into aerated nutrient solution pots. Maize plants were grown in a climate 
room under strictly regulated environmental conditions. Relative humidity was maintained between $65-75 \%$, the light/dark cycle was $16 / 8 \mathrm{hrs}$. with a respective $25 / 20^{\circ} \mathrm{C}$ temperature periodicity, and light intensity was kept at the constant $300 \mu \mathrm{mol} \mathrm{m} \mathrm{m}^{-2} \mathrm{~s}^{-1}$ during daytime.

\section{Plant growth in nutrient solution}

The nutrient solution used for plant growth had the following composition: $2.0 \mathrm{mM} \mathrm{Ca}\left(\mathrm{NO}_{3}\right)_{2}, 0.7 \mathrm{mM}$ $\mathrm{K}_{2} \mathrm{SO}_{4}, 0.5 \mathrm{mM} \mathrm{MgSO}_{4}, 0.1 \mathrm{mM} \mathrm{KH}_{2} \mathrm{PO}_{4}, 0.1 \mathrm{mM} \mathrm{KCl}$, $0.1 \mu \mathrm{M} \mathrm{H}_{3} \mathrm{BO}_{3}, 0.5 \mu \mathrm{M} \mathrm{MnSO}_{4}, 0.5 \mu \mathrm{M} \mathrm{ZnSO}_{4}$ and $0.2 \mu \mathrm{M} \mathrm{CuSO}_{4}$. Iron was supplied in the form of $10^{-4}$ M Fe-EDTA, too (Cakmak and Marschner 1990).

Selenium was supplemented to the nutrient solution as two species of selenite in the form of $\mathrm{Na}_{2} \mathrm{SeO}_{3}$ and selenate in the form of $\mathrm{Na}_{2} \mathrm{SeO}_{4}$ in five different concentrations, as follows: 0 (control), 0.1, 0.3, 0.9 and $3 \mathrm{mg} \mathrm{L}^{-1}$.

Nutrient solution was changed every 3 days and evaporated water was replenished regularly. The experiment ended 2 weeks after planting, when the third leaf of the control treatment had completely grown and seedlings had approximately $40-30 \mathrm{~cm}$ long shoots and roots respectively. Experiments were carried out in triplicates (three pots) that every pot had four seedlings.

\section{Sample preparation}

At the end of the experiment shoots were separated from roots. Plant parts were dried at $70{ }^{\circ} \mathrm{C}$ until constant weight was achieved, then cooled to room temperature and weighed using an analytical scale (OHAUS, Swiss). Dried samples $(0.01,0.5$ or $1 \mathrm{~g}$, depended on our samples' amount) were homogenized and digested by $\mathrm{HNO}_{3}-\mathrm{H}_{2} \mathrm{O}_{2}$ treatment (Kovács et al. 1996). Briefly, samples were kept in 1,5 or $10 \mathrm{ml}$ concentrated $\mathrm{HNO}_{3}$ overnight, then heated to $60^{\circ} \mathrm{C}$ for $45 \mathrm{~min}$ in a LABOR MIM OE 718/A block digestion apparatus. Following the first digestion step, $0.3,1.5$ or $3 \mathrm{ml} 30 \% \mathrm{H}_{2} \mathrm{O}_{2}$ were added to the samples and digestion was continued at $120{ }^{\circ} \mathrm{C}$ for another $90 \mathrm{~min}$. After cooling the samples to room temperature, volume was adjusted to 5, 25 or $50 \mathrm{ml}$ with deionized water. Samples were then mixed by shaking and filtered through FILTRAK 388 filters.

\section{Quantification of selenium}

Total selenium content was measured on a Thermo Fisher Scientific model X-Series II inductively coupled plasma mass spectrometer (ICP-QMS) equipped with Hexapole Collision Cell Technology (CCT). For quantification of selenium content $1 \mathrm{ml}$ of digested sample was diluted to $5 \mathrm{ml}$ by the addition of $3.9 \mathrm{ml}$ water and $0.1 \mathrm{ml} 5 \mathrm{mg}$ rhodium $\mathrm{l}^{-1}$ solution as an internal standard.

As collision/reaction gas 7\% hydrogen $93 \%$ helium gas mixture was applied at a flow rate $6 \mathrm{ml} \mathrm{min}^{-1}$. The sample introduction system consisted of a Meinhard type concentric nebulizer interfaced with a quartz conical spray chamber with impact bead cooled down to $2{ }^{\circ} \mathrm{C}$ by Peltier chiller. Nickel sampler and skimmer cones were used with $1.0 \mathrm{~mm}$ and $0.7 \mathrm{~mm}$ orifice ID respectively. The sample solutions were pumped at a rate of $0.5 \mathrm{ml} \mathrm{min}^{-1}$ by a peristaltic pump from tubes arranged on a CETAC ASX 520 Model auto sampler (CETAC, Omaha, Nebraska, USA). Instrument was controlled by Plasma Lab (ver. 2.5.10.319, Thermo Fisher Scientific, Bremen, Germany) software.

The system operation e.g. ion lens voltage, torch position etc. were daily optimized with a multielement standard solution (Thermo Fisher Scientific, Bremen, Germany) (10 $\left.\mu \mathrm{g} \mathrm{L}^{-1}\right)$ according to the standard daily optimization procedure recommended by the manufacturer. Optimization was performed with respect to the maximum ion intensity reaching $>400000$ integrated counts per second for cobalt and uranium, and $>800000$ for indium, also the oxides and doubly charged ion formation was minimized by monitoring on the ${ }^{156} \mathrm{CeO}^{+} / 140 \mathrm{Ce}^{+}$and ${ }^{138} \mathrm{Ba}^{2+} / 138 \mathrm{Ba}^{+}$; ratios which were kept below $1 \%$. The ions were detected with a secondary electron multiplier operating in dual mode (pulse counting or analogue mode). Typical instrument settings were, RF power $1.4 \mathrm{~kW}$, plasma gas flow rate $14.0 \mathrm{~L} \mathrm{~min}^{-1}$, auxiliary gas flow rate $1.00 \mathrm{~L} \mathrm{~min}^{-1}$ and nebulizer gas flow rate of $0.90 \mathrm{~L} \mathrm{~min}^{-1}$. Signals were measured using $100 \mathrm{~ms}$ dwell time and 9 sweeps for all isotopes as a main run with 3 replications.

\section{Statistical analyses}

All data were statistically analyzed using SPSS 17.0 software, and the mean values of each treatment group were subjected to multiple comparisons analysis using the One-Way ANOVA and a significance level of $p<0.05$.

The bars indicate the standard error of the mean. Significant differences in the mean value of each treatment group are indicated by different lowercase letters based on the LSD test $(p<0.05, n=3)$ when the distribution of data were homogenous and Games-Howell test $(\mathrm{p}<0.05$, $n=3$ ) when the distribution of data were not homogenous.

\section{RESULTS AND DISCUSSION}

\section{Comparison of $\mathrm{Se}^{\mathrm{IV}}$ uptake effects on maize shoot and root}

Figure 1 displays Se contents of shoot and root at different concentrations of $\mathrm{Se}^{\mathrm{IV}}$. Se content significantly increased due to increasing the application of $\mathrm{Se}^{\mathrm{IV}}$ and its amount in root is more than shoot in all of treatments.

Table 1 shows changes of fresh and dry weight of shoots and roots by increasing the application of $\mathrm{Se}^{\mathrm{IV}}$. Control and $3 \mathrm{mg} \mathrm{L}^{-1} \mathrm{Se}^{\mathrm{IV}}$ samples have the most and the least fresh and dry weights respectively in both shoots and roots.

Figure 2 illustrates $\mathrm{Se}^{\mathrm{IV}}$ uptake effect on maize at different concentrations and high dose $\mathrm{Se}^{\mathrm{IV}}$ toxicity in samples which had been treated with $3 \mathrm{mg} \mathrm{L}^{-1} \mathrm{Se}^{\mathrm{IV}}$, is obvious. 
Figure 1: Comparison of $\mathrm{Se}^{\mathrm{IV}}$ uptake effect on maize shoot and root
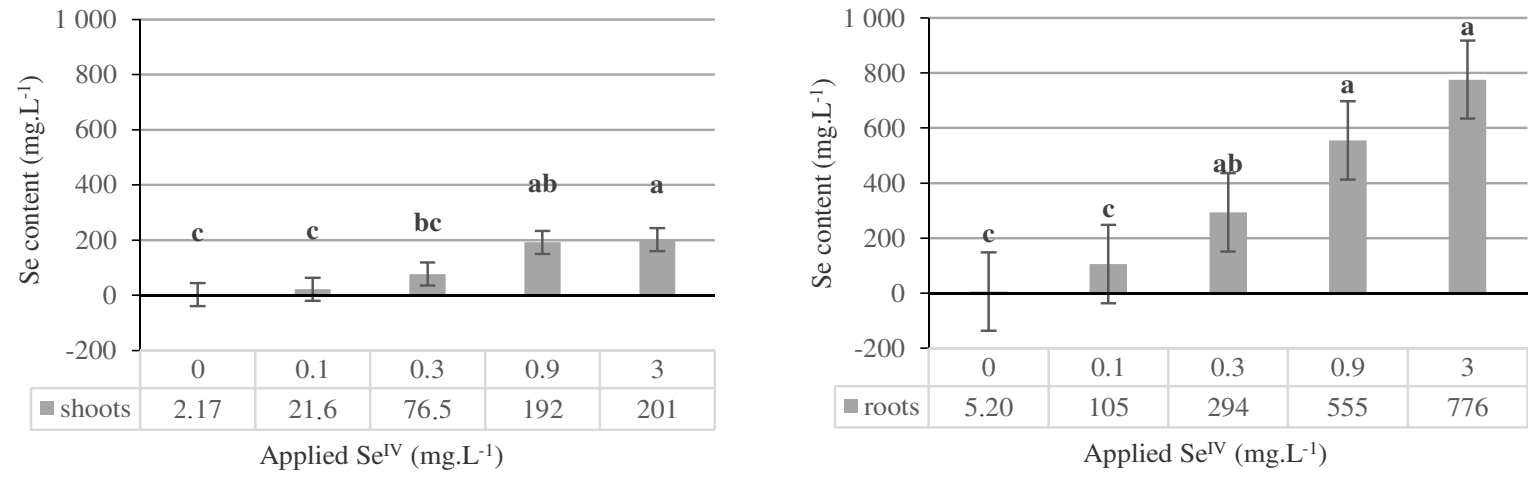

Note: significant differences in the mean value of each treatment group are indicated by different lowercase letter based on the GamesHowell test $(\mathrm{p}<0.05, \mathrm{n}=3 \pm$ s.e. $)$

Table 1 .

Comparison of different concentrations of $\mathrm{Se}^{\mathrm{IV}}$ uptake effects on fresh and dry weight of shoots and roots

\begin{tabular}{lcccc}
\hline \multirow{2}{*}{ Applied Se $\left(\mathrm{mg} \mathrm{1}^{-1}\right)$} & \multicolumn{2}{c}{ Shoots } & \multicolumn{2}{c}{ Roots } \\
\cline { 2 - 5 } & Fresh weight $(\mathrm{g})$ & Dry weight $(\mathrm{g})^{\mathrm{a}}$ & Fresh weight $(\mathrm{g})$ & Dry weight $(\mathrm{g})$ \\
\hline 0 & $3.4760 \pm 0.2637^{\mathrm{a}}$ & $0.2632 \pm 0.0255^{\mathrm{a}}$ & $1.6431 \pm 0.1630^{\mathrm{a}}$ & $0.0989 \pm 0.0100^{\mathrm{ab}}$ \\
0.1 & $2.7697 \pm 0.2815^{\mathrm{b}}$ & $0.2087 \pm 0.0234^{\mathrm{b}}$ & $1.3972 \pm 0.1319^{\mathrm{a}}$ & $0.0816 \pm 0.0073^{\mathrm{b}}$ \\
0.3 & $2.9544 \pm 0.6297^{\mathrm{ab}}$ & $0.2329 \pm 0.0319^{\mathrm{ab}}$ & $1.7253 \pm 0.3283^{\mathrm{a}}$ & $0.1007 \pm 0.0169^{\mathrm{ab}}$ \\
0.9 & $2.6551 \pm 0.2834^{\mathrm{b}}$ & $0.2315 \pm 0.0183^{\mathrm{ab}}$ & $1.7792 \pm 0.3092^{\mathrm{a}}$ & $0.1096 \pm 0.0136^{\mathrm{a}}$ \\
3 & $0.5369 \pm 0.0264^{\mathrm{c}}$ & $0.0618 \pm 0.0036^{\mathrm{c}}$ & $0.4850 \pm 0.0399^{\mathrm{b}}$ & $0.0377 \pm 0.0039^{\mathrm{c}}$ \\
\hline
\end{tabular}

Note: significant differences in the mean value of each treatment group are indicated by different lowercase letter based on the LSD test $(\mathrm{p}<0.05, \mathrm{n}=3 \pm$ s.e. $)$

Figure 2: $\mathbf{S e}^{\mathrm{IV}}$ uptake effect on maize at different concentrations

(from left: control, $0.1,0.3,0.9,3 \mathrm{mg} \mathrm{L}^{-1} \mathrm{Se}^{\mathrm{IV}}$ treatments)

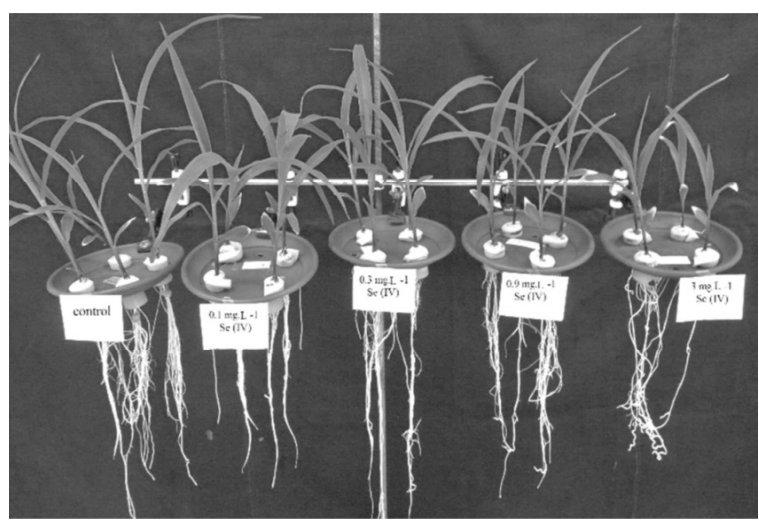

\section{Comparison of $\mathrm{Se}^{\mathrm{VI}}$ uptake effects on maize shoot} and root

Se content of shoots and roots significantly increased due to increasing the application of $\mathrm{Se}^{\mathrm{VI}}$ as it has been shown in Figure 3 and its amount in root is more than shoot in all of the treatments but in the case of $3 \mathrm{mg} \mathrm{L}^{-1}$ treatment, there is a contrast that shoot samples have more Se content.

Table 2 shows changes of fresh and dry weight of maize shoots and roots by increasing the application of $\mathrm{Se}^{\mathrm{VI}}$ and as we see, samples that had been treated with $0.1 \mathrm{mg} \mathrm{L}^{-1} \mathrm{Se}^{\mathrm{VI}}$ have the most fresh and dry weights although on the whole there is not any significant difference between all of the treatments.

Figure 4 illustrates $\mathrm{Se}^{\mathrm{VI}}$ uptake effect on maize at different concentrations.

Figure 3: Comparison of $\mathrm{Se}^{\mathrm{VI}}$ uptake effect on maize shoot and root

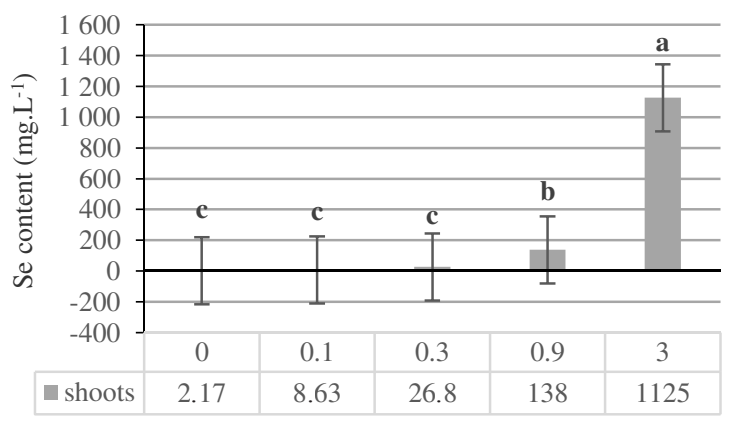

Applied $\mathrm{Se}^{\mathrm{VI}}\left(\mathrm{mg} . \mathrm{L}^{-1}\right)$

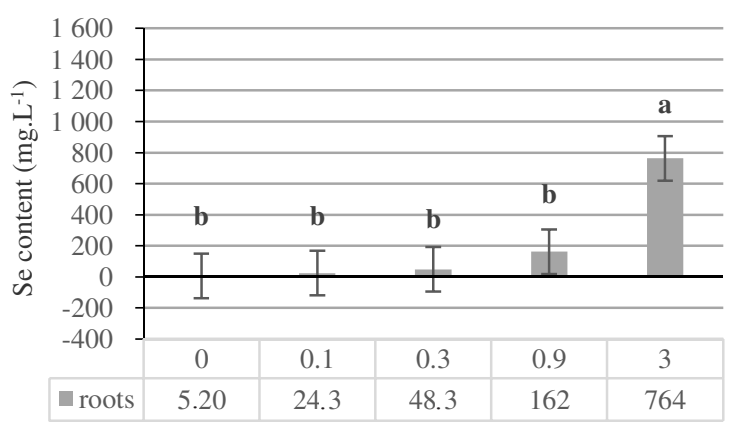

Applied SeVI $\left(\mathrm{mg} . \mathrm{L}^{-1}\right)$

Note: significant differences in the mean value of each treatment group are indicated by different lowercase letter based on the GamesHowell test $(\mathrm{p}<0.05, \mathrm{n}=3 \pm$ s.e. $)$ 
Comparison of different concentrations of $\mathrm{Se}^{\mathrm{VI}}$ uptake effects on fresh and dry weight of shoots and roots

\begin{tabular}{lcccc}
\hline \multirow{2}{*}{ Applied Se $\left(\mathrm{mg} \mathrm{l}^{-1}\right)$} & \multicolumn{2}{c}{ Shoots } & \multicolumn{2}{c}{ Roots } \\
\cline { 2 - 5 } & Fresh weight $(\mathrm{g})$ & Dry weight $(\mathrm{g})$ & Fresh weight $(\mathrm{g})$ & Dry weight $(\mathrm{g})$ \\
\hline 0 & $3.4760 \pm 0.2637^{\mathrm{a}}$ & $0.2632 \pm 0.0255^{\mathrm{a}}$ & $1.6431 \pm 0.1630^{\mathrm{a}}$ & $0.0989 \pm 0.0100^{\mathrm{a}}$ \\
0.1 & $4.1070 \pm 1.3455^{\mathrm{a}}$ & $0.3011 \pm 0.0905^{\mathrm{a}}$ & $1.8678 \pm 0.6821^{\mathrm{a}}$ & $0.1067 \pm 0.0368^{\mathrm{a}}$ \\
0.3 & $3.2581 \pm 0.6369^{\mathrm{a}}$ & $0.2471 \pm 0.0397^{\mathrm{a}}$ & $1.6172 \pm 0.1869^{\mathrm{a}}$ & $0.0919 \pm 0.0109^{\mathrm{a}}$ \\
0.9 & $2.9850 \pm 0.4136^{\mathrm{a}}$ & $0.2336 \pm 0.0260^{\mathrm{a}}$ & $1.5506 \pm 0.3685^{\mathrm{a}}$ & $0.0871 \pm 0.0192^{\mathrm{a}}$ \\
3 & $3.2889 \pm 1.1539^{\mathrm{a}}$ & $0.2683 \pm 0.0902^{\mathrm{a}}$ & $1.4476 \pm 0.4550^{\mathrm{a}}$ & $0.0977 \pm 0.0330^{\mathrm{a}}$ \\
\hline
\end{tabular}

Note: significant differences in the mean value of each treatment group are indicated by different lowercase letter based on the LSD test $(\mathrm{p}<0.05, \mathrm{n}=3 \pm$ s.e. $)$

Figure 4: $\mathrm{Se}^{\mathrm{VI}}$ uptake effect on maize at different concentrations

(from left: control, 0.1, 0.3, 0.9, $3 \mathrm{mg} \mathrm{L}^{-1} \mathrm{Se}^{\mathrm{VI}}$ treatments)

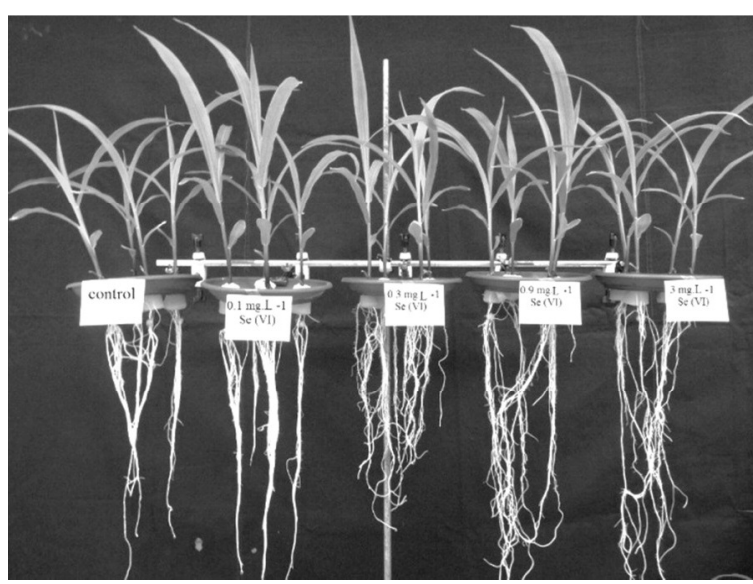

\section{CONCLUSIONS}

Due to the high demand of food across the world, its enrichment with essential micronutrients, such as $\mathrm{Se}$, is crucial and therefore, plants play an important role in Se supplementation (Finley 2005). However, Se can also be toxic when ingested in high concentrations (Gaso et al. 2000, Hartikainen 2005).

Our experiment showed the Se content in shoots and roots of maize increased as the Se concentration applied increased.

Furthermore, although the mobility amount of selenite and selenate in hydroponic systems are the same, due to the lower energy consumption required for uptake, selenite $(+4)$ exhibited higher toxicity than selenate $(+6)$, as the results for fresh and dry weight of shoots and roots confirm.

Moreover, the presented results allow us to conclude Se content in the maize roots are more than the shoots.

\section{REFERENCES}

Broadley, M. R--Alcock, J--Alford, J-Cartwright, P.-FairweatherTait, S. J.-Foot, I.-Hart, D. J.-Hurst, R.-Knott, P.-McGrath, S P.-Meacham, M. C.-Norman, K.-Mowat, H.-Scott, P.-Stroud, J. L.-Tovey, M.-Tucker, M.-White, P. J.-Young, S. D.-Zhao, F. J. (2010): Selenium biofortification of high-yielding winter wheat (Triticum aestivum L.) by liquid or granular Se fertilisation. Plant Soil. 332: 5-18.

Cakmak, I.-Marschner, H. (1990): Decrease in nitrate uptake and increase in proton release in zinc deficient cotton, sunflower and buckwheat plants. Plant and Soil. 129: 261-268.

Canton, S. P.-Van Derveer, W. D. (1997): Selenium toxicity to aquatic life: an argument for sediment-based water quality criteria. Environ. Toxicol. Chem. 16: 1255-1259.

Carvalho, K. M.-Martin, D. F. (2001): Removal of aqueous selenium by four aquatic plants. J. Aquat. Plant Manage. 39: 33-36.

Clark, L. C.-Dalkin, B.-Krongrad, A.-Combs, Jr. G. F.-Turnbull, B. W.-Slate, E. H. (1998): Decreased incidence of prostate cancer with selenium supplementation: results of a double-blind cancer prevention trial. Br. J. Urol. 81: 730-4.

Della Rovere, F.-Granata, A.-Familiari, D.-Zirilli, A.-Cimino, F.Tomaino, A. (2006): Histamine and selenium in lung cancer. Anticancer Res. 26: 2937-42.

Eurola, M. (2005): Proceedings: Twenty Years of Selenium Fertilization. Helsinki. Finland. 8-9 September 2005.
Eurola, M.-Hietaniemi, V.-Kontturi, M.-Tuuri, H.-Kangas, A.Niskanen, M.-Saas-tamoinen, M. (2004): Selenium content of Finnish oats in 1997-1999: effect of cultivars and cultivation techniques. Agr. Food Sci. 13: 46-53.

Fan, T. W. M.-Teh, S. J.-Hinton, D. E.-Higashi, R. M. (2002): Selenium biotransformations into proteinaceous forms by foodweb organisms of selenium-laden drainage waters in California Aquat. Toxicol. 57: 65-84.

Finley, J. W. (2005): Selenium Accumulation in Plant Foods. Nutr. Res. 63: 196-202.

Gaso, M. I.-Segovia, N.-Morton, O.-Servantes, M. L.-Godinez, L.Pena, P.-Acosta, E. (2000): Cs and relationship with major and trace elements in edible mushrooms from México. Sci. Total Environ. 262: 73-89.

Grau, M. V.-Rees, J. R.-Baron, J. A. (2006): Chemoprevention in gastrointestinal cancers: current status. Basic Clin. Pharmacol. Toxicol. 98: 281-287.

Hartikainen, H. (2005): Biogeochemistry of selenium and its impact on food chain quality and human health. J. Trace Elem. Med. Biol. 18: 309-318

Ježek, P.-Škarpa, P.-Lošák, T.-Hlušek, J.-Jůzl, M.-Elzner, P. (2012) Selenium - An Important Antioxidant in Crops Biofortification. [In: El-Missiry, M. A. (ed.) Antioxidant Enzyme.] Croatia. EPublishing Inc. 343-368. 
Kovács, B.-Győri, Z.-Prokisch, J.-Loch, J.-Dániel, P. (1996): A study of plant sample preparation and inductively coupled plasma emission spectrometry parameters. Commun. Soil Sci. Plant Anal. 27. 5-8: 1177-1198.

Lyons, G. H.-Judson, G. J.-Ortiz-Monasterio, I.-Genc, Y.-Stangoulis, J. C. R.-Graham, R. D. (2005): Selenium in Australia: selenium status and biofortification of wheat for better health. J. Trace Elem. Med. Biol. 19: 75-82.

Shen, L.-Van Dyck, K.-Luten, J.-Deelstra, H. (1997): Diffusibility of selenate, selenite, seleno-methionine, and seleno-cystine during simulated gastrointestinal digestion. Biol. Trace Elem. Res. 58: 55-63.
Terry, N.-Zayed, A. M.-de Souza, M. P.-Tarun, A. S. (2000): Selenium in higher plants. Annual Review of Plant Physiology and Plant Molecular Biology. 51: 401-432.

Weiller, M.-Latta, M.-Kresse, M.-Lucas, R.-Wendel, A. (2004): Toxicity of nutritionally available selenium compound in primary and transformed hepatocytes. Toxicology. 201: 21-30.

White, P. J.-Broadley, M. R. (2009): Bio fortification of crops with seven mineral elements often lacking in human diets-iron, zinc, copper, calcium, magnesium, selenium and iodine. New Phytol. 182: 49-84. 
